LEONARDO MARIANELLI $^{(\text {a) }}$ - IMMACOLATA IOVINELLA ${ }^{(a)}$ - AGOSTINO STRANGI ${ }^{\text {(a) }}$ - LUCA MADONNI $^{\text {(a) }}$ - KONSTANTIN A. EFETOV (b) - GERHARD M. TARMANN ${ }^{(c)}$ - VERONICA RAIOLA (d) - FRANCESCO BARUZZO $^{(\mathrm{d})}$ - GIUSEPPINO PEVERIERI SABBATINI $^{(\mathrm{a})}$ - PIO FEDERICO ROVERSI ${ }^{(\mathrm{a})}$

\title{
FIRST RECORD OF THE PEST ARTONA (FUSCARTONA) MARTINI EFETOV, 1997 (LEPIDOPTERA ZYGAENIDAE PROCRIDINAE ARTONINI) IN EUROPEAN TERRITORY
}

(a) CREA Research Centre for Plant Protection and Certification, Firenze, Italy

(b) V.I.Vernadsky Crimean Federal University, Department of Biological Chemistry and Laboratory of Biotechnology, 295051 Simferopol, Crimea

(c) Sammlungs-und Forschungszentrum der Tiroler Landesmuseen, Krajnc-Straße 1, A-6060 Hall, Austria

(d) Regional Phytosanitary Service of Liguria, Genova, Italy

\begin{abstract}
Marianelli L., Iovinella I., Strangi A., Madonni L., Efetov K.A., Tarmann G.M., Raiola V., Baruzzo F., Peverieri Sabbatini G., Roversi P.F. - First record of the pest Artona (Fuscartona) martini Efetov, 1997 (Lepidoptera Zygaenidae Procridinae Artonini) in European territory.

Artona (Fuscartona) martini Efetov, 1997 (black bamboo moth) was detected for the first time in Europe near Genova (Italy) in 2019 in a bamboo naturalized area. In this area, the exotic bamboo plants have found suitable climatic conditions for growth and outcompete other native forest species growing in fresh and humid environments such as hazel, poplar and alder. A. martini is one of the most harmful organisms associated with bamboo ornamental plants and bamboo plantations and represents their most common pest in eastern China, Taiwan, Japan (including Okinawa and Ogasawara Islands), and Vietnam. Recently it has been recorded in New Zealand and Korea. Due to the increasing agricultural and commercial interest for bamboo as an ornamental plant and as a resource for woody biomass production, the presence of this alien insect is noteworthy, representing a new possible phytosanitary problem for the European territory.
\end{abstract}

Keywords: black bamboo moth, bamboo, pest, EU, Italian territory, alien species.

\section{INTRODUCTION}

Artona (Fuscartona) martini Efetov, 1997 (Lepidoptera, Zygaenidae) is a black coloured Asian moth, belonging to a world-wide distributed family with more than 1,000 species (EFETOV and TARMANN, 2017). The Lepidoptera family Zygaenidae is represented by five subfamilies: Inouelinae Efetov \& Tarmann, 2017; Procridinae Boisduval, 1828; Chalcosiinae Walker, 1865; Callizygaeninae Alberti, 1954; and Zygaeninae Latreille, 1809 (TARMANN, 1994; EFETOV, 1999; EFETOV et al., 2014; EFETOV and TARMANN, 2014a; EFETOV and TARMANN, 2017).

Artona martini (black bamboo moth), belonging to the tribe Artonini Tarmann, 1994 of the subfamily Pocridinae, was described by EFETOV (1997) in the genus Artona Walker, 1854 from the native area in China, Taiwan, Japan and Vietnam. Later the genus Fuscartona Efetov and Tarmann 2012 with A. martini as its type species was described (EFETOV and TARMANN, 2012). According to the contemporary point of view (EFETOV and TARMANN, 2017), Fuscartona is considered as a subgenus of the genus Artona. Thus, the systematic status of this species is Artona (Fuscartona) martini Efetov, 1997. This species was also recorded from southern Japanese territories: Ogasawara (INOUE, 1998) and Okinawa Islands (TomINAGA, 2001). In 1996 this species was recorded, for the first time, in New Zealand, in seven areas within the Wahangarei district and, in a few years, it expanded its infested area becoming a serious phytosanitary problem (GILL, 2000). In 2009 A. martini was detected for the first time also in Korea (Hongneung, Seoul) (BYUN et al., 2010).

Artona martini has many morphological features similar to other species belonging to the same subgenus occurring in south-east Asia, viz. Artona (Fuscartona) funeralis (Butler, 1879), A. (F.) uniformis (Alberti, 1954), and A. (F.) parilis Efetov, 1997.

Identification of Artona (Fuscartona) species is based on numerous morphological characters, e.g. male and female genitalia, the forewing and body colour. The colour of the proboscis, in particular, is one of the most evident characters for a clear taxonomic identification. A. martini, unlike the other species listed above (with a yellow proboscis), has a brown proboscis (EFETOV, 1997). Other morphological and biological characteristics of the treated species are well described in EFETOV (1997) and GILL (2000). Adults of this moth have blackish body and forewings, with weak blue reflection (Fig. I). The male is slightly smaller than the female that could measure just over $1 \mathrm{~cm}$ in length.

Artona martini spread in new territories of New Zealand within two years; infact, it has been found in four different sites within a radius of $10 \mathrm{~km}$ from the introduction area, indicating that the moth can disperse wherever the host plant is grown (GILL, 2000). In the original area, $A$. martini adults are active between the end of April and the beginning of October; during this period this species can complete up to two or three generations per year (EFETOV, 1997). 
Eggs are laid in correspondence with the nodes of the host-plants or on the leaves (EFETOV, 1997). The first instar larvae have a characteristic Artonini chaetotaxy, namely the first abdominal segment with only one dark dorsal seta; in addition there are also one dark subdorsal and two light lateral setae (EFETOV and HAYASHI, 2008). The young larvae are light yellow coloured and gradually develop a darker colouration during maturation. The caterpillars have black verrucae on each body segment (Fig. I). Just before the pupal stage, the length of the mature larvae is around $25 \mathrm{~mm}$. The skin of the larva is covered with urticating hairs that, as well as in other Lepidoptera species, likely have a defence function against predators such as birds and small rodents (MURPHY et al., 2010; BATTISTI et al., 2011). As reported by Gill (2000), contact with urticating hairs of the larvae can produce skin irritation in susceptible persons and animals. This could represent a human health problem during the development of gradation .

Artona martini larvae feed on various host-plants of the family Poaceae: Shibataea kumasasa (Zoll.) Makino ex Nakai, Pleiobastus auricomus (Mitford) D.C. McClint., Phyllostachys nigra (Lodd.) Munro, Miscanthus sinensis Andersson, and Bambusa multiplex (Lour.) (YEN et al., 1996; EfETOV, 1997; SUGI, 1997; GILL, 2000); in its natural range they also feed on Phyllostachys makinoi Hay. and P. pubescens Mazel ex Houz (YeN et al., 1996; EFETOV, 1997; HOARE, 2001). Larvae, from the the first instars, eat the surface of the bamboo leaves and produce small windows in the mesophyll and the yellowing of the leaves, causing a severe defoliation (GILL, 2000).

In this study, we report the first interception of black bamboo moth A. martini in European territory.

\section{MATERIALS AND METHODS}

\section{ORIGIN OF THE INSECTS}

In 2019, October 31st phytosanitary inspectors observed numerous yellowish larvae feeding on infested Phyllostachis sp. plants located in an area along the banks of the Lavagna river, 4421'54" N; 09¹9'53" E (WGS84) (Liguria region, Italy). Larvae were collected by Veronica Raiola and Francesco Baruzzo, phytosanitary inspectors, and reared in the laboratory, in entomological cages. A few days after, in 2019 November 6th, during a second inspection in the bamboo area, mature larvae were found pupating in papery brown oval cocoons on the host leaves and in some crevices and holes in cut bamboo stems.

Samples of larvae, adults and other biological materials of $A$. martini are preserved in $96 \%$ ethanol in the entomological collection at the CREA - Council for Agricultural Research and Economics - Research Centre for Plant Protection and Certification (CREADC) in Florence (Sample ID:5043-5052), for further studies.

\section{TAXONOMY IDENTIFICATION}

From around 10 larvae and 20 cocoons collected during the first inspection, reared in the lab on bamboo leaves (conditions: $26 \mathrm{C}$ - RH 60\% - 12:12 L:D), only two females come out from the chrysalis. They were used for species identification by Konstantin Efetov on the base of the study of habitus and genitalia characters. Adult genitalia were dissected after incubation of the abdomens in $20 \% \mathrm{KOH}$ solution at $60 \mathrm{C}$ for 1 hour. Voucher specimens are deposited at V. I. Vernadsky Crimean Federal University, Department of Biological Chemistry and Laboratory of Biotechnology. The genitalia preparation is placed in a plastic microtube with glycerol and pinned under the specimen.

\section{MOLECULAR ANALYSIS}

A single caterpillar was collected in the field from the infested bamboo plant and stored in $96 \%$ ethanol until analysis. DNA was extracted using Blood and Tissue DNA Extraction Kit (QIAGEN) following the protocol suggested by the manufacturer. The final elution step was performed in $100.0 \mu \mathrm{l}$ of AE Buffer supplied with the commercial kit. A fragment of COX I mitochondrial gene was amplified using the primers LCO1490 and HCO2198 (FOLMER et al., 1994). PCR reaction was performed in a total volume of $50.0 \mu \mathrm{l}$ containing $25.0 \mu \mathrm{l}$ of DreamTaq Hot Start PCR Master Mix 2X (Thermo Fisher), 0.6 mM each primer and 50.0 ng of DNA. The temperature program was $95^{\circ} \mathrm{C}$ for 3 min, then 45 cycles of $94^{\circ} \mathrm{C}$ for $45 \mathrm{sec}, 45^{\circ} \mathrm{C}$ for $45 \mathrm{sec}$ and $72^{\circ} \mathrm{C}$ for $1.5 \mathrm{~min}$, followed by a single cycle at $72 \mathrm{C}$ for 5min. The obtained PCR amplicon was sequenced and submitted in GenBank. Sequence comparison was performed using Nucleotide database with BLAST algorithm and BOL Database query.

Voucher specimens are preserved in 96\% ethanol in the entomological collection at the CREA - Council for Agricultural Research and Economics - Research Centre for Plant Protection and Certification (CREADC) in Florence.

\section{RESULTS AND DISCUSSION}

Lepidoptera collected in the Italian bamboo infested area have been identified as Artona (Fuscartona) martini Efetov, 1997.

Female genitalia of $A$. martini have a typical structure (Fig. II). The ostium bursae is not sclerotized. The antrum is tubular with two characteristic sclerotized ventral folds distally. In the female genitalia of many species of Procridinae a special structure exists, named "praebursa". The praebursa is the strongly dilated distal part of the ductus bursae between the antrum and the corpus bursae (EFETOV, 1996; EFETOV and TARMANN, 2013a; EFETOV and TARMANN, 2013b; EFETOV and TARMANN, 2014a; EFETOV and TARMANN, 2014b; EFETOV and TARMANN, 2016). The praebursa in $A$. martini is well developed, ovoid in shape, with 1-3 sclerotized small spines on the ventral wall near the antrum and with a long longitudinal double row of toothlike sclerotizations. The corpus bursae is significantly smaller than the praebursa, oval, translucent, without signa. 

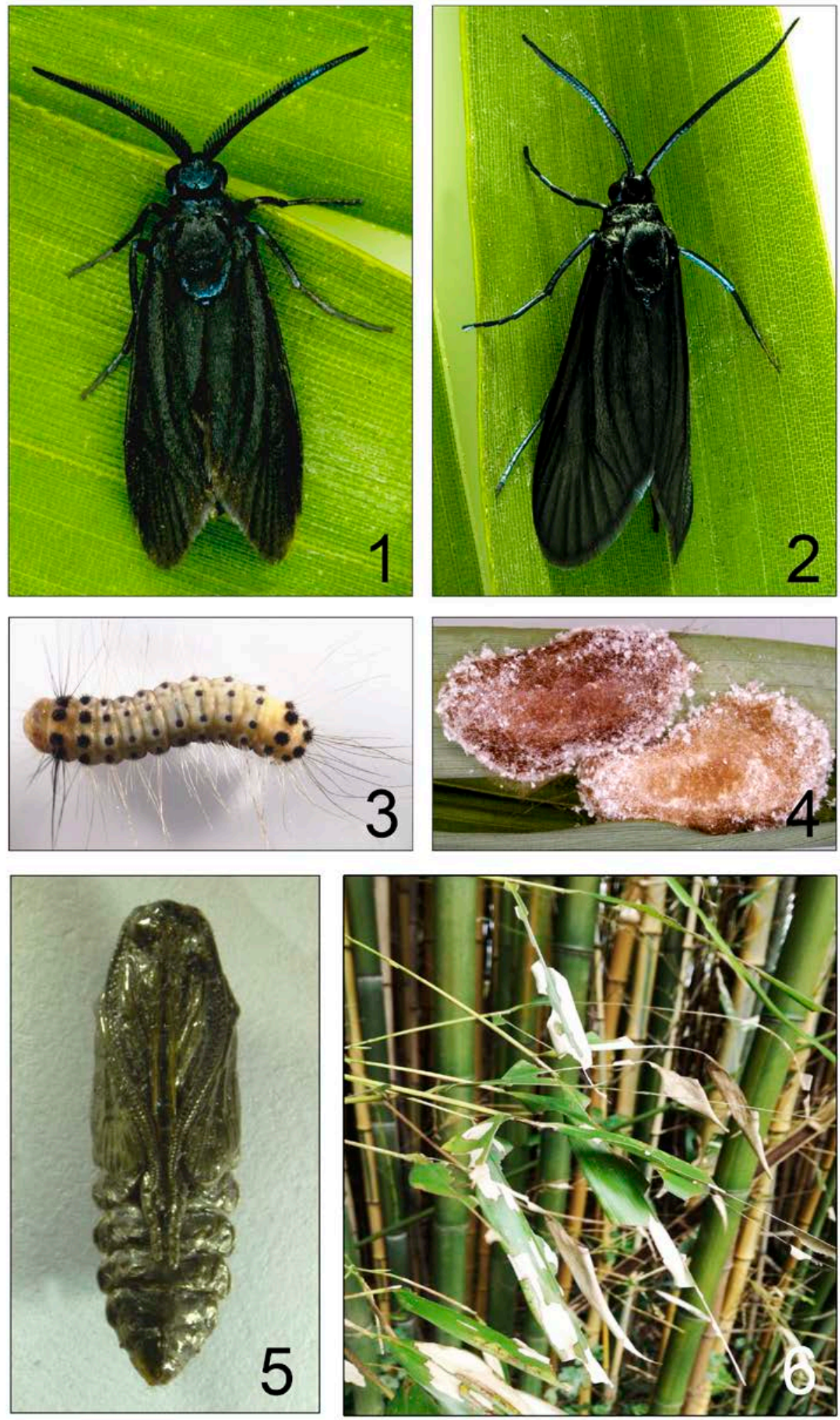

Fig. I -Artona (Fuscartona) martini Efetov, 1997: Adult male (1); adult female (2); mature larva (3). cocoon on bamboo leaves (4); chrysalis (5); damaged bamboo leaves (6). 


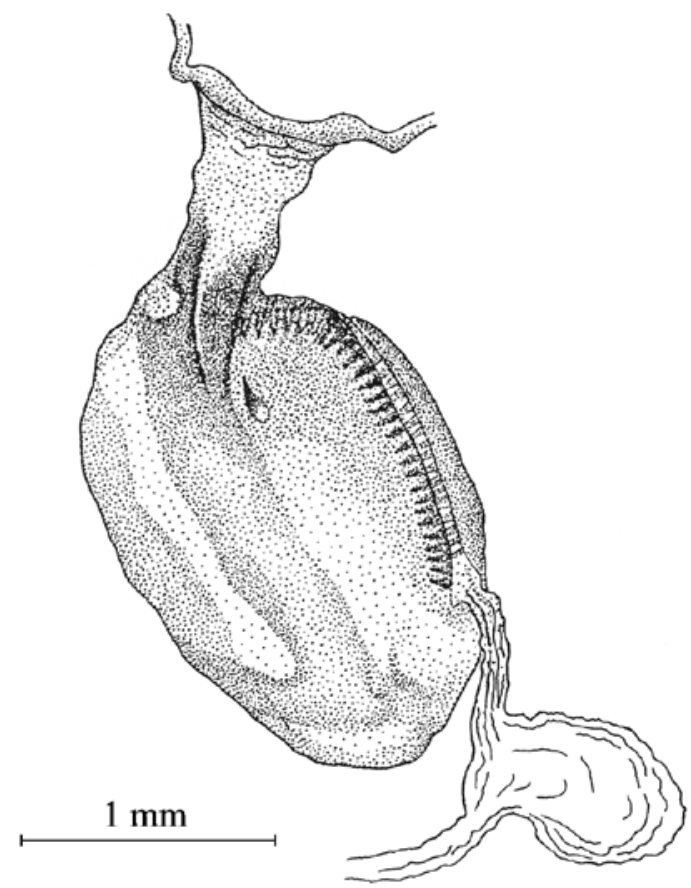

Fig. II - Female genitalia of Artona (Fuscartona) martini Efetov, 1997 (after Efetov, 1997).

In order to define a molecular reference for this species, sequencing of the 5' fragment of COX I gene was performed and the resulting sequence was submitted to GenBank under the accession MT052886.

Although wide dataset for DNA-barcoding in Palaearctic Lepidoptera has been published (e. g. HAUSMANN et al., 2011; DAPPORTO et al. 2019; Efetov et al., 2019), this species was still absent from the main repositories (BOLD, GenBank) and the only sequence that could be associated with the samples was referred to an unspecified Zygaenidae (GenBank Accession: LC477292).

Even though a sequence from a single specimen do not harbour the variability of the fragment in the whole species, the availability of a DNA-barcoding sequence in public repositories will allow a correct identification not only of adults but also of immature instars where morphological characters are less clear. This will represent an important opportunity for a quick detection of possible infestations.

The A. martini discovery in a natural bamboo area near Genova represents the first interception of these Zygaenidae for Europe. During the inspection, some dead larvae of $A$. martini colonized by a mycelium resembling Beauvaeria bassiana Vuill. (1912) were observed; the samples were collected and are still under study. Other larvae were parasitized by the endoparasite Compsilura concinnata (Meigen, 1824), a cosmopolitan Diptera (Tachinidae) already reported in association with A. martini in China (LIU et al., 1998).

This alien species could interfere with the bamboo natural expansions in areas where the bamboo is an alien species and considered to be a weed plant, as along the Lavagna river. In these areas bamboo is out of control and these plants grow in spatial continuity, in the territories once occupied by hygrophilous endemic plant species such as poplar, alder and hazel.

The economic impact of this alien insect could be related to the bamboo industry in Europe. This nicheindustry is a promising perspective in a sustainable economy (POTTERs et al., 2013). Bamboo, besides ornamental plant purposes, could be used in the production of enhanced MDF-plates (KOUYOUMJI and LANVIN, 2000), textile fibres (DESHPANDE et al., 2000), bio-fuel (BRIDGWATER, 1996; EL BASSAM et al., 1999) and source of metabolites that could be tested in cosmetics and pharmaceutical applications (VAN HOYWEGHEN et al., 2010).

Further studies are thus necessary to assess the pathway of the introduction of $A$. martini, its current distribution, the possibility to establish and spread in the Italian and European territory, as it occurred in New Zealand. Moreover, it is also extremely interesting to understand the impacts of this new insect on bamboo ornamental plants and plantation crop of bamboo in Italy, to develop efficacious management policies to prevent other introductions and to control the possible stabilized population.

\section{ACKNOWLEDGEMENT}

The authors want to thank to Dr. Gian Paolo Barzanti for identification of mycelium isolated from A. martini larvae and Prof. Pierfilippo Cerretti for the specific identification of Diptera endoparasite. The research was supported by the Italian Ministry of Agricultural Food and Forestry Policies - MIPAAF (grant project “Protezpiante” DM 0034140 29/12/2017).

\section{REFERENCES}

Battisti A., Holm G., FAgrell B., LARSSON S., 2011 - Urticating Hairs in Arthropods: Their Nature and Medical Significance. - Annual Review of Entomology, 56: 203-220.

BRIDGWATER A., 1996 - Production of high grade fuels and chemicals from catalytic pyrolysis of biomass. Catalysis today, 29: 285-295.

BYUn B.K., LEE B.W., KIM I.K., KIM J., PARK I.K., SHIN S.C., 2010 - A first discovery of Artona martini Efetov (Lepidoptera: Zygaenidae) from Korea. Journal of Asia-Pacific Entomology, 13: 391-393.

DAPPORTO L., Cini A., VODĂ R., DinCĂ V., WiEMERS M., Menchetti M., Magini G., Talavera G., ShreEVE TG., BONElli S., CASACCI L. P., BAlletTo E., SCALERCIO S., VILA, R., 2019 Integrating three comprehensive data sets shows that mitochondrial DNA variation is linked to species traits and paleogeographic events in European butterflies. - Molecular Ecology Resources, 19:1623-1636.

DESHPANDE A.P., BHASKAR RAO M., LAKSHMANA RAO C., 2000 - Extraction of bamboo fibers and their use as reinforcement in polymeric composites. - Journal of Applied Polymer Science, 76: 83-92. 
Efetov K. A., Hofmann A., TARmann G. M., TREMEWAN W.G., 2014 - Taxonomic comments on the treatment of the Zygaenidae (Lepidoptera) in volume 3 of Moths of Europe, Zygaenids, Pyralids 1 and Brachodids (2012). - Nota Lepidopterologica, 37: 123-133.

EFETOV K.A., 1996 - The description of the female of Illiberis (Alterasvenia) yuennanensis Alberti, 1951 (Lepidoptera: Zygaenidae, Procridinae). Entomologist's Gazette, 47: 111-113.

EFETOV K.A., 1997 - Two new species of the genus Artona Walker, 1854 (Lepidoptera: Zygaenidae, Procridinae). - Entomologist's Gazette, 48: 165-177.

EFETOV K.A., 1999 - Inouela gen. $n$. from Japan and Taiwan (Lepidoptera: Zygaenidae, Chalcosiinae). Entomologist's Gazette, 50: 91-98.

EFETOV K.A., HAYASHI E., 2008 - On the chaetotaxy of the first instar larva of Artona martini Efetov, 1997 (Lepidoptera: Zygaenidae, Procridinae, Artonini). Entomologist's Gazette, 59: 101-104.

EFETOV K.A., TARMANN G.M., 2012 - A checklist of the Palaearctic Procridinae (Lepidoptera: Zygaenidae).- Crimean State Medical University Press, Simferopol - Innsbruck: 108 pp.

EFETOV K.A., TARMANN G.M., 2013a - Chrysartona (Chrystarmanna) mineti sp. nov.(Lepidoptera: Zygaenidae, Procridinae) from northern Vietnam. Entomologist's Gazette, 64: 197-206.

EFETOV K.A., TARMANN G.M., 2013b - Illiberis (Alterasvenia) cernyi sp. nov. (Lepidoptera: Zygaenidae, Procridinae) from northern Thailand. Entomologist's Gazette, 64: 33-39.

EFETOV K.A., TARMANN G.M., 2014a - Illiberis (Alterasvenia) banmauka sp. nov.(Lepidoptera: Zygaenidae, Procridinae) from China and Myanmar. - Entomologist's Gazette, 65: 62-70.

EFETOV K.A., TARMANN G.M., 2014b - A new European species, Adscita dujardini sp. nov. (Lepidoptera: Zygaenidae, Procridinae) confirmed by DNA analysis. - Entomologist's Gazette, 65: 179200.

EFETOV K.A., TARMANN G.M., 2016 - Pseudophacusa multidentata Efetov \& Tarmann, a new genus and species of Procridini from Myanmar, China and Laos (Lepidoptera: Zygaenidae, Procridinae). - SHILAP Revista de Lepidopterología, 44: 81-89.

EFETOV K.A., TARMANN G.M., 2017 - The hypothetical ground plan of the Zygaenidae, with a review of the possible autapomorphies of the Procridinae and the description of the Inouelinae subfam. nov. - The Journal of the Lepidopterists' Society, 71: 20-49.

EFETOV K.A., KirsanOVA A.V., LAZAREVA Z.S., PARShKOVA E.V., TARMANN G.M., RougerIE R., HEBERT P.D.N., 2019 - DNA barcoding of Zygaenidae (Lepidoptera): results and perspectives. - Nota Lepidopterologica, 42: 137-150

El Bassam N., Meier D., Gerdes C., Korte A., 1999 - Modern biofuels from bamboo: bio-oil, charcoal and gas. - Temperate Bamboo Quarterly IV, 1: 1218.
FOLMER O., BLACK M., HOEH W., LUTZ R., VRIJENHOEK R., 1994 - DNA primers for amplification of mitochondrial Cytochrome C oxidase subunit I from diverse metazoan invertebrates. - Molecular Marine Biology and Biotechnology, 3: 294-299.

GILL G., 2000 - A first record of Artona (Balataea) martini (Lepidoptera: Zygaenidae) for New Zealand. - New Zealand Entomologist, 23: 33-35.

Hausmann A., Haszprunar G., SEgerer A. H., SPEIDEL W., BEHOUNEK G., HEBERT P. D., 2011 Now DNA-barcoded: the butterflies and larger moths of Germany. - Spixiana, 34: 47-58.

HOARE R.J., 2001 - Adventive species of Lepidoptera recorded for the first time in New Zealand since 1988. - New Zealand Entomologist, 24: 23-47.

InOUE H., 1998 - The Zygaenidae, Hyblaeidae, Thyrididae, Limacodidae, Uraniidae, Sphingidae, Arctiidae and Nolinae (Noctuidae) of the Ogasawara Islands, with additions and corrections to the Geometridae and Pyralidae (Lepidoptera): Moths of Ogasawara (Bonin) Islands, Part IV. Transactions of the Lepidopterological Society of Japan, 49: 271-287.

KouYOUMJI J.L., LANVIN J.D., 2000 - Bamboo for Europe, Final Report.- CTBA (Technical Centre for Wood and Furniture), Bordeaux: 199 pp.

LIU Y.Z., CHAO C.M., LI L.F., ZHOU S.X., WANG H.X., ZHANG W.J., 1998 - Fauna of Tachinidae from Shanxi Province.- Science Press, Beijing: 378 pp.

MURPHY S.M., LEAHY S.M., WILLIAMS L.S., LILL J.T., 2010 - Stinging spines protect slug caterpillars (Limacodidae) from multiple generalist predators. Behavioral Ecology, 21: 153-160.

PotTers G., Schutte F., VAN Goethem D., DenOlLiN S., SAMSON R., GIELIS J., 2013 - Bamboo as a crop in Western Europe-a SWOT analysis. - Acta Horticultura, 1003: 89-96.

SUGI S., 1997 - Artona funeralis (Butler) and A. martini Efetov (Zygaenidae, Procridinae), two species confused. - Japan Heterocerists' Journal, 196: 339343.

TARMANN G.M., 1994 - A preliminary review of the classification of the zygaenid subfamily Procridinae (Lepidoptera). - Nota lepidopterologica, Supplement, 5: 115-123.

TOMINAGA S., 2001 - Occurrence of Artona martini Efetov (Zygaenidae) in Okinava. - Yugato, 163: 14.

VAN HoyWeghen L., Karalic I., VAN CALENBERGH S., DEFORCE D., HEYERICK A., 2010 - Antioxidant flavone glycosides from the leaves of Fargesia robusta. - Journal of Natural Products, 73: 15731577.

YEN S.H., JEAN J.L., YANG P.S., 1996 - On two Artona species from Taiwan (Lepidoptera: Zygaenidae, Procridinae). - Entomologist's Gazette, 47: 99-108. 